\title{
KING EIDER AT YELLOWKNIFE - DECEMBER 1983
}

KEVIN MCCORMICK, Habitat Biologist, Canadian Wildlife Service, Yellowknife, N.W.T., X1A 2 N5 and ROBERT G. BROMLEY, Waterfowl Ecologist, N.W.T. Department of Renewable Resources, Yellowknife, NW.T. X1A 2L9

On 12 December 1983 a juvenile female King Eider was picked up near the airport at Yellowknife, Northwest Territories. The bird was flying overhead when attacked and knocked to the ground by two Common Ravens ( $M$. Marion pers. comm.). The eider, which weighed $1.2 \mathrm{~kg}$, was in good physical condition. The bird was collected and the skin was preserved and donated to the National Museum of Natural Sciences, Ottawa.

In Canada, the King Eider breeds throughout the arctic islands and along the mainland coast from northern Yukon to southern Hudson Bay. It is apparently uncommon in northern Quebec and Labrador. ${ }^{4} 5$ The breeding range is occupied by both western and eastern populations which either meet or have a zone of overlap at about longitude 100o-110o W. ${ }^{5}$ The western population winters north to the limit of open water in the Bering Sea and south to the Aleutian Islands whereas the eastern population winters primarily from southern Greenland to Newfoundland. ${ }^{4} 5$

The western population migrates around Alaska along the coastline whereas most of the eastern population reaches southern Greenland via water routes (Lancaster Sound or Hudson Strait) around Baffin Island. Dates of departure from breeding areas vary greatly. Adult birds, including post-incubating females, depart before becoming flightless but do not go all the way to the wintering areas. Birds arrive, at both wintering areas, during late November - early December. ${ }^{5}$
The occurrence of a King Eider in the southern Mackenzie District is not unique. In October 1903, Preble observed four individuals on the Mackenzie River near Fort Simpson. ${ }^{6}$ Also, an adult male was collected east of Fort Resolution during spring 1904. ${ }^{6}$ Additional spring observations include an adult male collected in Yellowknife Bay on Great Slave Lake in June 1938 and a few more recent observations in the same area (field notes of the late William L. McDonald, Yellowknife). Fall observations outside of Mackenzie District are comprised of 1 immature male at Blackstrap Lake, Saskatchewan, remaining in the area through mid-November, 1983 and $1 \mathrm{im}$ mature male near Calgary, Alberta on 4 November 1984.8 7

Young of the year, and those older birds, mostly females, that remain longest on breeding grounds make up the later fall flocks. Murdock states that "small flocks and single birds are to be seen till the sea closes ...."6 Young eiders have been observed in large creches (up to 100 birds) through September in the central arctic, but fall migration of the species remains poorly known. ${ }^{2}$ Flock concluded that the waterfowl migration was ongoing at least through the first week of November at Point Barrow, Alaska. ${ }^{3}$ Based on his own studies, Barry presumed that these waterfowl were largely young eiders.

Despite such late departure dates from the arctic as October and early November, a mid-December observation in Yellowknife at an ambient temperature 
Table 1. MEAN MINIMUM AND MEAN MAXIMUM TEMPERATURES (oC) FOR YELLOWKNIFE AND CAMBRIDGE BAY, N.W.T., DURING NOVEMBER AND DECEMBER 1983.*

$\begin{array}{lcccc} & \text { November } & \begin{array}{c}\text { Cambridge Bay } \\ \text { December }\end{array} & \text { November } & \text { Oellowknife } \\ \text { Mean minimum } & -8.6 & -30.0 & -20.4 & -30.1 \\ \text { Departure from normal } & \$ 9.4 & -2.0 & \$ 6.9 & \$ 3.8 \\ \text { Mean maximum } & -3.3 & -21.7 & -14.1 & -22.4 \\ \text { Departure from normal } & \$ 6.8 & -1.8 & \$ 5.7 & \$ 4.0\end{array}$

* Data provided by Atmospheric Environment Services, Environment Canada, Yellowknife.

of $-40^{\circ} \mathrm{C}$ is extremely unusual. We reviewed mean minimum and maximum temperatures for November and December 1983, in comparison to long term averages in an attempt to explain the late appearance of the eider (Table 1). We selected the locations of Yellowknife where the eider was recovered, and Cambridge Bay, N.W.T. the nearest likely departure point for the bird. Cambridge Bay is centrally located in the heart of the species' breeding range. We found that November (Yellowknife and Cambridge Bay) and December (Yellowknife) of 1983 were unusually mild and may have permitted an extended stay or higher survival of late hatched young than normally would have occurred.

Palmer suggested that scattered birds, if forced to move, may take a fairly direct southward course. ${ }^{5}$ The present occurrence is consistent with this conjecture. Such a rare departure of a young bird from the major migration pathways may have resulted from the lack of adult guide birds, which would long since have migrated.
BARRY, T.W. 1983. Eider ducks of the western Canadian arctic. Unpubl. rept., Can. Wildl. Serv., Edmonton. 25 pp.

2 BARRY, T.W., S.J. BARRY and B. JACOBSON. 1981. Sea-bird surveys in the Beaufort Sea, Amundsen Gulf, Prince of Wales Strait, and Viscount Melville Sound - 1980 season. Unpubl. rept., Can. Wildl. Serv., Edmonton. 69 pp.

${ }^{3}$ FLOCK, W.L. 1973. Radar observations of bird movements along the Arctic coast of Alaska. Wilson Bull. 85:259-275.

${ }^{4}$ GODFREY, W.E. 1966. The birds of Canada. Bull. 203, Biology Series 72, National Museums of Canada, Ottawa. 428 pp.

5 PALMER, R.S. 1976. Handbook of North American birds, 3, Part II, Yale Univ. Press, New Haven. 521 pp.

${ }^{6}$ PREBLE, E.A. 1908. A biological investigation of the Athabasca - Mackenzie region. North American Fauna No. 27, U.S. Dept. of Agric., Washington. 574 pp.

7 SALT, W.R. and J.R. SALT. 1976. The birds of Alberta. Hurtig Publ., Edmonton. 498 pp.

${ }^{8}$ SMITH, A.R. 1984. First record of the King Eider in Saskatchewan. Blue Jay 42(2):91-92. 